\title{
EXPERIMENTAL STUDY OF COMPARISON OF SIMPLE VCRS AND VCRS WITH PHASE CHANGE MATERIAL(PCM) AS POTASSIUM CHLORIDE (KCL)
}

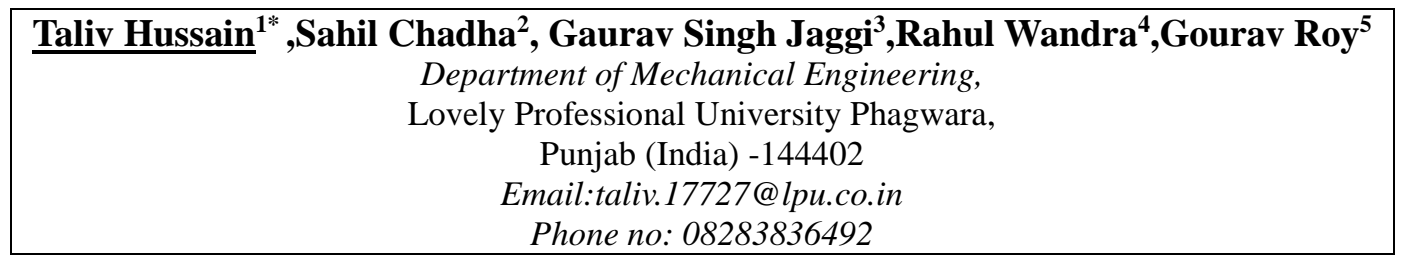

\begin{abstract}
The performance of heat transfer is most essential area of research in the field of thermal engineering. For the process of heat transfer there are huge numbers of refrigerants which can be used to transfer the heat from low temperature reservoir to high temperature reservoir by using vapour compression refrigeration system. The vapour compression refrigeration technology has made a great improvement over a few decades in the form of efficiency of cycle through significant efforts of thermal engineers and manufacturers. The modification of cycle should be investigated to enhance the efficiency of the system. In this paper the experimental study is conducted to predict the comparison between the Simple VCRS and the VCRS with Phase change material (PCM) as KCL (potassium chloride) on the evaporator. In this paper the use of PCM can further decrease the temperature of the evaporator. We mainly bring the focus on to decrease the temperature of evaporator as lowest as possible so there is need of PCM. The use of PCM directly enhances the performance of the system by 21-25\%.So by the use of the Phase change material there is an increment in the coefficient of performance (COP) of the system.
\end{abstract}

Keywords: Phase change material, KCL, vapour compression refrigeration system, $C O P$

\section{INTRODUCTION}

Vapour compression refrigeration system is a system which is used to transfer heat from low reservoir to the high reservoir by the use of a working fluid known as a refrigerant. It is a system which uses the high grade energy results in the increase of coefficient of performance. Vapour compression refrigeration system which consists of certain parts such as Compressor, Evaporator, Condenser and Expansion valve. It has smaller size for the given capacity of refrigeration. This refrigeration system can be employed over a large range of temperatures and the coefficient of performance of this refrigeration system is quite high. To further increase the coefficient of performance the PCM (Phase change material) can be used in the evaporator and to get the lowest temperature of evaporator the PCM can also be used. It has the main advantage that it has the less running cost. In this refrigeration system the low pressure and temperature vapour refrigerant is drawn into the compressor through the inlet or suction valve where it is compressed to a high pressure and temperature. The high pressure and temperature vapour refrigerant is discharged into the condenser through the delivery or discharge valve. So this refrigeration uses the compressor work which is a high grade energy which implies that the amount of energy used in the system is totally converted into the useful work which helps to increase the coefficient of performance of this refrigeration system.

\section{LITERATURE REVIEW}

Webb (1984) developed a unified theoretical treatment of evaporative systems: cooling towers, evaporative coolers and evaporative condensers. His model considered the effect of the variation in temperature of the deluge water in an evaporative cooler, but stated that for an evaporative condenser the film temperature remains essentially constant due to the fact that the variation in the refrigerant temperature is negligibly small.

Y.S.Lee and C.C.Su have studied the performance vapour compression refrigeration system with isobutene (R600a) as refrigerant and compare the results with R12 and R22. They used R600a about $150 \mathrm{~g}$ and set the refrigeration temperature about $4{ }^{\circ} \mathrm{C}$ and $-10{ }^{\circ} \mathrm{C}$ to maintain the situation of cold storage and freezing applications. They used $0.7 \mathrm{~mm}$ internal diameter and 4 to $4.5 \mathrm{~m}$ length of capillary tube for cold storage applications and $0.6 \mathrm{~mm}$ internal diameter and 4.5 to $5 \mathrm{~m}$ length of capillary tube for freezing applications. They observed that the COP lies between 1.2 and 4.5 in cold storage applications and between 0.8 and 3.5 in freezing applications.

A.S. Dalkilic and S. Wongwises [1], have studied the performance on a vapourcompression refrigeration system with refrigerant mixtures based on R134a, R152a, R32, $\mathrm{R} 290, \mathrm{R} 1270, \mathrm{R} 600$ and R600a was done for various ratios 


\section{ELK Asia Pacific Journals - Special Issue} ISBN: 978-81-930411-4-7

\section{Asia Pacific Journals}

and their results are compared with R12, R22 and R134a as possible alternative replacements. The results showed that all of the alternative refrigerants investigated in the analysis have a slightly lower COP than R12, R22, and R134a for the condensation temperature of $50{ }^{\circ} \mathrm{C}$ and evaporating temperatures ranging between $-30{ }^{\circ} \mathrm{C}$ and $10{ }^{\circ} \mathrm{C}$. Refrigerant blends of R290/R600a (40/60 by wt. \%) instead of R12 and R290/R1270 (20/80 by wt. \%) instead of R22 are found to be replacement refrigerants among other alternatives.

Yinhai Zhu and Peixue Jiang [4] developed a refrigeration system which combines a basic vapor compression refrigeration cycle with an ejector cooling cycle. The ejector cooling cycle is driven by the waste heat from the condenser in the vapor compression refrigeration cycle. The additional cooling capacity from the ejector cycle is directly input into the evaporator of the vapor compression refrigeration cycle the system analysis shows that this refrigeration system can effectively improve the COP by the ejector cycle with the refrigerant which has high compressor discharge temperature.

Andrea Chesi, Giovanni Ferrara, Lorenzo Ferrari and Fabio Tarani [5] analyze a complex system in which the solar powered ejection machine is used to increase the efficiency of a traditional vapor compression machine by subtracting heat from the condenser. By means of a transient analysis, performed with a reference building and with climate data corresponding to four different system locations worldwide, the year-round performance of such a system in a space cooling application is estimated in terms of energy balance and savings on power costs with respect to the traditional solutions.

A. Selvaraju and A. Mani [6] investigate the experimental analysis of the performance of a vapor ejector refrigeration system. The system uses R134a as working fluid and has a rated cooling capacity of $0.5 \mathrm{~kW}$. The influence of generator, evaporator and condenser temperatures on the system performance is studied. For a given ejector configuration, there exists an optimum temperature of primary vapor at a particular condenser and evaporating temperatures, which yields maximum entrainment ratio and COP.

\section{EXPERIMENTAL SETUP}

This experimental setup involves simple vapour compression refrigeration system with the basic parts such as evaporator, compressor, expansion device and condenser. This setup includes the reciprocating compressor and refrigerator R134a. In this system the phase change material $(\mathrm{KCL})$ is also used in order to increase the coefficient of performance. In this particular setup air cooled condenser is used for the better heat transfer results. In this particular setup the PCM i.e KCL is used to enhance the performance and to obtain the better heat transfer rate.

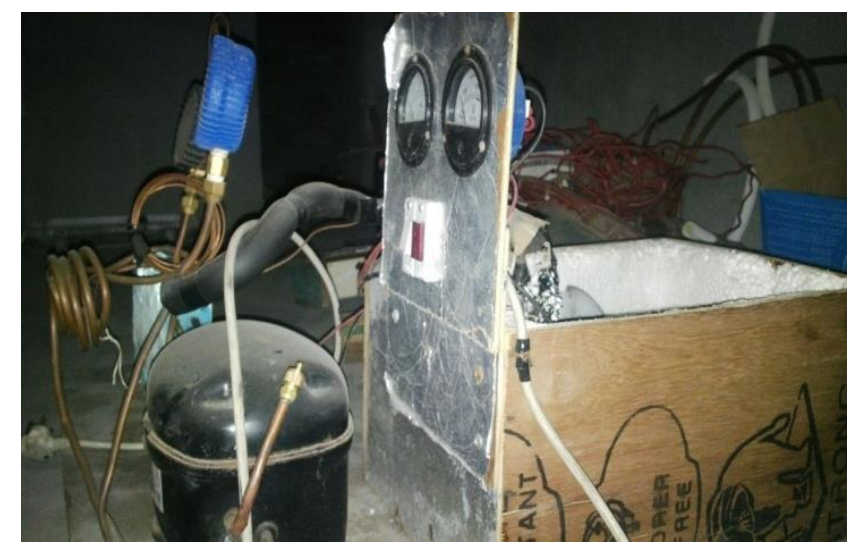

Fig:1 Experiment setup

\section{MEASURING DEVICES}

1. Pressure Gauge: The bourdon pressure gauges are used to measure the suction (inlet) and discharge(outlet) pressure of compressor.

2. Thermocouple: Temperatures of refrigerant and the ambient air at different points are measured by use of RTD PT100 type thermocouples.

3. Voltmeter and Ammeter: Ammeter and voltmeter are used to measure the electrical current and voltage of input power respectively.

Before temperature measurement, the surface of the tubes is polished for removing any type of dust or rust and then the thermocouples are laid onto the surface. Insulation tapes are wrapped around the copper tubes to prevent any heat losses to ambient air. 
ELK

Asia Pacific Journals

\begin{tabular}{|c|c|c|c|c|c|}
\hline \multirow{2}{*}{ Parameters } & \multirow{2}{*}{$\begin{array}{l}\text { Unit and } \\
\text { Symbol }\end{array}$} & \multicolumn{2}{|c|}{$\begin{array}{c}\text { Simple VCRS } \\
\text { system }\end{array}$} & \multicolumn{2}{|c|}{$\begin{array}{l}\text { VCRS with } \\
\text { (Kcl) PCM }\end{array}$} \\
\hline & & $\begin{array}{l}\text { At } \\
27^{\circ} \mathrm{C}\end{array}$ & $\begin{array}{l}\text { At } \\
30^{\circ} \mathrm{C}\end{array}$ & $\begin{array}{l}\text { At } \\
27^{\circ} \mathrm{C}\end{array}$ & $\begin{array}{l}\text { At } \\
30{ }^{\circ} \mathrm{C}\end{array}$ \\
\hline $\begin{array}{l}\text { Suction } \\
\text { Pressure }\end{array}$ & Bar & 0.24 & 0.55 & 0.43 & 0.51 \\
\hline $\begin{array}{c}\text { Discharge } \\
\text { Pressure }\end{array}$ & Bar & 9.72 & 9.49 & 11.16 & 10.43 \\
\hline $\begin{array}{c}\text { Evaporator } \\
\text { Outlet } \\
\text { Temperature }\end{array}$ & $\begin{array}{c}\text { Degree } \\
\text { Celsius }\left({ }^{\circ} \mathrm{C}\right)\end{array}$ & $\begin{array}{c}- \\
12.93\end{array}$ & $\begin{array}{c}- \\
13.31\end{array}$ & -17.1 & -16 \\
\hline $\begin{array}{c}\text { Compressor } \\
\text { Outlet } \\
\text { Temperature }\end{array}$ & $\begin{array}{c}\text { Degree } \\
\text { Celsius }\left({ }^{\circ} \mathrm{C}\right)\end{array}$ & 44.12 & 50.21 & 44 & 43.5 \\
\hline $\begin{array}{c}\text { Condenser } \\
\text { Outlet } \\
\text { Temperature }\end{array}$ & $\begin{array}{c}\text { Degree } \\
\text { Celsius }\left({ }^{\circ} \mathrm{C}\right)\end{array}$ & 31.44 & 31.51 & 33.3 & 32.5 \\
\hline Current & Ampere(A) & 1.21 & 1.80 & 0.69 & 0.99 \\
\hline Voltage & Volt $(\mathrm{V})$ & 190 & 190 & 190 & 190 \\
\hline
\end{tabular}

\section{OBSERVATION TABLE}

Table 1: Result obtained by using PCM (Kcl) and simple VCRS

\section{CALCULATION AND RESULTS}

Based on the experimental results, thermodynamic properties of the refrigerant at different points in the cycle are obtained using the $\mathrm{P}-\mathrm{H}$ chart of refrigerant $\mathrm{R}-134 \mathrm{a}$ and the parameters such as mass flow rate, cooling capacity and $\mathrm{COP}$ of the system are calculated from the equations:
ELK Asia Pacific Journals - Special Issue ISBN: 978-81-930411-4-7
A. Compressor Work $\mathrm{W}_{\mathrm{c}}=\mathrm{V} * \mathrm{I}=m_{r e f} *\left(\mathrm{~h}_{2}-\mathrm{h}_{1}\right)$
B. Mass flow rate of refrigerant $m_{r e f}=\frac{W c}{(h 2-h 1)}$
C. Cooling effect produced Qr $=m_{r e f} *\left(\mathrm{~h}_{1}-\mathrm{h}_{4}\right)$
D. $\mathrm{COP}=\frac{\mathrm{Qr}}{\mathrm{Wc}}$

Where,

h1 = enthalpy of refrigerant at inlet of compressor in $\mathrm{kj} / \mathrm{kg}(1)$

$\mathrm{h} 2=$ enthalpy of refrigerant at exit of compressor in $\mathrm{kj} / \mathrm{kg}(2)$

h3 = enthalpy of refrigerant at exit of the condenser $\mathrm{kj} / \mathrm{kg}(3)$

h4 = enthalpy of refrigerant at entry of evaporator in $\mathrm{kj} / \mathrm{kg}(4)$

Table 2: Result of the experiment at ambient air temperature $27^{\circ} \mathrm{C}$

\begin{tabular}{|c|c|c|c|}
\hline \multicolumn{4}{|c|}{ Performance result of Air Conditioner $\left(\mathbf{T}_{\text {amb-27 }}{ }^{\circ} \mathrm{C}\right)$} \\
\hline Parameter & Unit & $\begin{array}{c}\text { Simple VCRS } \\
\text { system }\end{array}$ & $\begin{array}{l}\text { VCRS with } \\
(\mathrm{Kcl}) \mathrm{PCM}\end{array}$ \\
\hline $\begin{array}{c}\text { Compressor } \\
\text { work } \mathrm{W}_{\mathrm{c}}\end{array}$ & Watt & 229 & 131.1 \\
\hline $\mathrm{COP}$ & --------- & 3.75 & 4.74 \\
\hline
\end{tabular}

Table 3: Result of the experiment at ambient air temperature $30^{\circ} \mathrm{C}$

\begin{tabular}{|c|c|c|c|}
\hline \multicolumn{4}{|c|}{ Performance result of Air Conditioner $\left(\mathbf{T}_{\text {amb }}-\mathbf{3 0}^{\circ} \mathrm{C}\right)$} \\
\hline Parameter & Unit & $\begin{array}{l}\text { Simple } \\
\text { VCRS } \\
\text { system }\end{array}$ & $\begin{array}{l}\text { VCRS } \\
\text { with }(\mathrm{Kcl}) \\
\text { PCM }\end{array}$ \\
\hline $\begin{array}{c}\text { Compressor work } \\
\mathrm{W}_{\mathrm{c}}\end{array}$ & Watt & 342 & 188 \\
\hline COP & --------- & 3.87 & 4.53 \\
\hline
\end{tabular}


ELK

\section{Asia Pacific Journals}

\section{REFERENCES}

[1] R.L. Webb, A unified theoretical treatment for thermal analysis of cooling towers, evaporative condensers, and fluid coolers, ASHRAE Trans

$$
90 \text { (Part 2B) (1984) 398-415. }
$$

[2] Y.S. Lee, and C.C. Su, "Experimental studies of isobutene (R600a) as the refrigerant in domestic refrigeration system," Applied Thermal Engineering 22, pp. 507-519, 2002.

[3] A.S. Dalkilic, and S. Wongwises, "A performance comparison of vapour-compression refrigeration system usingvarious alternative refrigerants,International Communications in Heat and Mass Transfer, 37, pp. $1340-1349,2010$

[4] Yinhai Zhu and Peixue Jiang, "Hybrid vapor compression refrigeration system with an integrated ejector cooling cycle" International journal of refrigeration, vol.35, 2012, pp.68-78.

[5] Andrea Chesi, Giovanni Ferrara, Lorenzo Ferrari and Fabio Tarani " Suitability of coupling a solar powered ejection cycle with a vapour compression refrigerating machine" Applied Energy, vol.97, 2012, pp.374383.
ELK Asia Pacific Journals - Special Issue ISBN: 978-81-930411-4-7

[5]A. Selvaraju and A. Mani, "Experimental investigation on R134a vapor ejector refrigeration system", International Journal of Refrigeration, Vol.29 (2006) pp.1160-1166. 